\title{
On Cultivation of Intercultural Communication Competence in the Context of "the Belt and Road"
}

\author{
Rui $\mathrm{Hu}$ \\ School of International Languages and Cultures \\ Yunnan University of Finance and Economics \\ Kunming, China \\ 867117267@qq.com
}

\begin{abstract}
The Strategy of "the Belt and Road" has brought great challenges and higher requirements for the domestic intercultural talents. Based on the theoretical connotation of intercultural communication competence, the paper analyzes the approaches of cultivating intercultural communication competence in English language teaching in the context of "the Belt and Road"
\end{abstract}

Keywords-the Belt and Road, intercultural communication competence, English language teaching

\section{INTRODUCTION}

"The Belt and Road" refers to "the Silk Road Economic Belt and the 21st Century Maritime Silk Road". With the development of China's "The Belt and Road" initiative, China's opening to the outside world has gradually shifted from its former orientation towards the west to the global. The international exchanges between China and various countries becomes increasingly frequent, and the language is duty-bound to become the basic guarantee of crossing cultural barriers and promoting cultural exchanges. This undoubtedly puts forward higher requirements and challenges for the cultivation of talents of cross-cultural communication in China. The approaches of cultivating intercultural communication competence have also been endowed with connotation of new era.

\section{INTERCULTURAL COMMUNICATION COMPETENCE}

Intercultural communication competence is a very complicated problem, which has been discussed by international academia for more than half a century. How to cultivate this competence is also a hot topic. Under the new situation, we want to cultivate new talents with intercultural communication competence to work for the strategy of "the Belt and Road". First of all, we should clarify theoretical connotation of intercultural communication competence.

Scholars all over the world try to generalize, explain and define the intercultural communication competence from various perspectives, but there is no definition that is universally accepted. Developed from Chomsky's (1965) [1] linguistic competence, it is initially mentioned by Hymes (1972) [2] as communicative competence involving interactions among grammatical, psychological and socialcultural systems. Canale and Swain (1980) [3] proposed a new version which has four components: grammatical, sociolinguistic, discourse and strategic competence. Byram (1997) [4] has produced what is to date the most fully worked-out explanation of intercultural communication competence, which involves five components, that is, the kinds of knowledge and skills needed to mediate between cultures. These are specified as follows: (1) knowledge of self and other, of how interaction occurs, of the relationship of the individual to society; (2) knowing how to interpret and relate information; (3) knowing how to engage with the political consequences of education, being critically aware of cultural behaviors; (4) knowing how to discover cultural information; and (5) knowing how to be: how to relativize oneself and value the attitudes and beliefs of the other.

Although scholars have different ideas on the components of intercultural communication competence, we can find the common part, that is, cognitive, affective and behavioral components. The knowledge dimension should include three aspects: appropriate knowledge of interaction rules, cultural specific and general knowledge, and linguistic knowledge. Besides language skills, the knowledge ranges from other culture's historical background, its tradition, customs, beliefs, values and its nonverbal norms to the cultural difference from ours. "Affective competence facilitates cross-cultural adaptation by providing an emotional and motivational capacity of dealing with the various challenges of cross-cultural exchanges." (Kim,1994) [5] On the base of a deep understanding of their own culture, communicator should respect, understand and proactively exchange with other cultures. As the behavioral competence, communicators can solve the problems using their practical abilities, such as verbal or nonverbal abilities. On the base of these three dimensions approved by most scholars, this paper explore the approaches of cultivating intercultural communication competence in the context of "The Belt and Road"

\section{APPROACHES ON CULTIVATING INTERCULTURAL COMMUNICATION COMPETENCE}

The Strategy of "The Belt and Road" has brought great challenges and higher requirements for English language teaching. We should cultivate the senior talents who not only master foreign language but also have intercultural awareness, sensitiveness and knowledge. The purpose of 
College English teaching is to cultivate high quality and high level English professionals for the society and the country, so as to achieve the cultural and economic exchanges with the international community. As English teachers, we should explore the new ways of cultivating the students' intercultural communication competence from the three dimensions including cognitive, affective and behavioral components.

\section{A. From cognitive aspect}

1) Let students learn English varieties, not only British or American English.

With further economic globalization, the current foreign language education, which only aims at learning standard English or western culture, is far from meeting the needs of international cooperation and communication. We must not avoid contact with people from various cultural backgrounds whose English language is bound to carry the native culture of these countries. The result of the fusion of native culture and English is a variety of English varieties, such as Indian English and Singaporean English. We should give full tolerance and respect to different varieties of English. You can't blindly think that only British and American English is standard and other English is not authentic. This prejudice is a very big barrier against our intercultural communication. In English language teaching, we should let the students learn that English language is loaded with the all-embracing world culture, not just the British and American culture, and the main purpose of English learning is to communicate with people of various cultural backgrounds.

\section{2) Let students learn about cultures of the countries} along "the Belt and Road".

At present, the students are more aware of the culture and social system of the major developed countries in the west, and know little about the small and medium-sized developing countries. Under the background of "the Belt and Road", the focus of teaching intercultural communication should shift. We should give more attention to the national culture of the countries along "the Belt and Road", especially those in trade with China. Let students learn about the geographical, historical, political, economic, cultural and religious knowledge of these countries, and form a overall impression of the cultures. They should learn some cross-cultural communication strategies to improve their communication competence. After all, this is China's long-term development strategy.

3) Let students learn about Chinese tradition and culture.

Thorough understanding and mastering of Chinese traditional culture not only helps to maintain the confidence and the dignity of the individual in cross-cultural communication, but also promotes Chinese culture essence. Speak good Chinese story to the world. For the students, it is not only the study of foreign culture, but also the spread of native culture. Students should not only express foreign cultures in English, but also to use English to introduce
Chinese culture to the world. This requires us to increase the content of some traditional Chinese culture in the process of foreign language teaching to improve students' cultural literacy and enhance the sensitivity of cultural differences.

\section{B. From affective aspect}

In the face of cultural differences, students should respect and see objectively, and realize that different cultures will enrich the world instead of creating conflicts. Meanwhile, there are still many things people in the world share. If we can appreciate similarities and respect differences, we are able to predict the possible consequences of our acts and be tolerant of those of others(Zhang, 2008). [6] In international communication, students will encounter people from different cultural backgrounds and have to learn new ways of seeing and experiencing life. Only by keeping an open mind can they absorb new ideas and communicate successfully. They need not only being tolerant of others but also learning from others.

\section{From behavioral aspect}

Students are encouraged to participate in intercultural communication activities to improve students' intercultural practical ability. Domestic famous cross-cultural research scholar Hu Zhongwen has pointed out that one of the best way to improve the intercultural competence is speaking or communicating directly with native speakers of Englis, or learning their culture through direct contact. (Hu 1999.) [7]. Students are encouraged to participate in university student exchange programs, international volunteer activities, international academic conference, international summer camps, winter camp or training or practice of related companies abroad. This kind of experience can make the students actively integrate into the world, flexibly use language knowledge in cross-cultural activities, deeply understand other national cultures and customs, and accumulate intercultural communication strategies. Let students improve their intercultural communicative competence from the behavior level. If there is no condition of going abroad, students are also encourage to use the Internet, computer and other means to increase learning outside the classroom, e.g. magazines and newspapers, movies, TV programs, etc. All in all, various activities in and out of class, conducted by teachers or implemented by students, are all very helpful in stimulating learners interests, initiative and creativity, and ultimately beneficial to the cultivating of their intercultural competence.

\section{CONCLUSION}

The strategy of "the Belt and Road" is a great strategy for China to realize the "Chinese dream", which conforms to the inevitable trend of economic and cultural globalization and serves the common interests of all peoples. Under the new situation, we should actively transform old ideas of English language teaching and explore new modes of cultivating the intercultural communication competence on the basis of deep understanding of its theoretical connotation, to meet the requirements and provide enough intellectual support for "the Belt and Road". 


\section{REFERENCES}

[1] Chomsky, "Aspects of the Theory of Syntax," Cambridge, MA; Massachusetts Institute of Technology Press, 1965.

[2] D. Hymes, "Models of the interaction of language and social life", Directions in Socio Linguistics, New York, NY: Basil Blackwell, pp. 35-71.

[3] M. Canale, and M. Swain, "Theoretical basis of communicative approaches to second language teaching and testing", Applied Linguistics, Vol.1, No.1, pp. 1-47.

[4] M. Byram, "Teaching and Assessing Intercultural Communicative Competence," Bristol, England: Multilingual Matters.
[5] William B. Gudylamst and Young Yun Kim, "Communicating with Strangers : An Approach to Intercultural Communication," Shanghai: Shanghai Foreign Language Education Press, 2007, pp. 394

[6] A.L. Zhang, "Cross-cultural Communication," Chongqing: Chongqing University Press, 2008

[7] W.Z. Hu, "Outline of Cross-cultural Communication," Beijing: Foreign Language Teaching and Research Press, 1999. 